\title{
Vegetable Growers Perception and Awareness about Bhavantar Bharpai Yojna in Haryana
}

\author{
Sandeep Bhakar ${ }^{1 *}$, Sube Singh $^{2}$ and P. S. Sheharawat ${ }^{2}$ \\ ${ }^{1}$ DES (Extension Education), CCS HAU KrishiVigyan Kendra, Fatehabad, India \\ ${ }^{2}$ (Extension Education), CCS HAU, Hisar, India \\ *Corresponding author
}

\begin{abstract}
A B S T R A C T
India is the second largest producer of vegetables in the world and accounts for about 15 per cent of the world's production of vegetables. In Haryana, vegetables are grown over an area of 447 thousand hectares with production of 7.16 MT and contribute about 3.90 percent in country's vegetable production. Vegetables being perishable in nature, farmers had to sell their products at the harvest time when the prices are minimal resulting in a very low return for their produced products. To overcome the risks and to give right price of vegetables to its growers, Haryana government has launched Bhavanter Bharpai Yojna (BBY) in January, 2018. The present study was undertaken to know the awareness and perception of vegetable growers about BBY in Haryana. The study was conducted in randomly selected Hisar and Fatehabad districts of Haryana. A sample size of 80 vegetable growers was selected for present study. The study reveals that respondents have 45.66 per cent awareness about BBY. Average mean score of 6.85 indicated that respondents had not sufficient awareness about BBY. Most of the respondents (more than $60 \%$ ) were not aware about registration process, area verification, sale period, procedure of claiming benefit under BBY. The data regarding vegetable growers perception reveals that 86.25 per cent respondents agree with the statement that ' $\mathrm{BBY}$ is not much beneficial in the present scenario of vegetable prices (WMS $=0.86$ ) followed by the statement 'BBY is not effective without awareness (WMS $=0.85$ )', BBY is not beneficial for farmers as daily price of vegetables are not fixed on the basis of local Mandis (WMS $=0.84$ ), Simplification of process is required for BBY effectiveness( WMS $=0.83$ ), On line registration of $\mathrm{BBY}$ is a big hurdle for less educated/ illiterate farmers(WMS=0.81) were ranked First, second, third, fourth \& fifth respectively. From above results, it can be concluded that BBY can be more effective if the rates of the crops included in the schemes should be increased and simplify the registration process under BBY as perceived by the respondents.
\end{abstract}

\section{Introduction}

Vegetables are important constituents of Indian agriculture and nutritional security due to their short duration, high yield, nutritional richness, economic viability and ability to generate on-farm and off-farm employment. Our country is blessed with diverse agro- climates with distinct seasons, making it possible to grow wide array of vegetables.

Vegetables are vital sources of proteins, vitamins, minerals, dietary fibers, micronutrients, antioxidants and phytochemicals in our daily diet. India is the second largest producer of vegetables in the 
world (ranks next to China) and accounts for about $15 \%$ of the world's production of vegetables. The production level is over 184.4 MT and the total area under vegetable cultivation is around 10.26 million hectares in the year 2017-18 which is about $3.20 \%$ of the total area under cultivation in the country. In India, about 40 kinds of vegetables belonging to different groups are being cultivated and potato, tomato, onion, cabbage and cauliflower account for around $60 \%$ of the total vegetable production in the country. In Haryana, vegetables are grown over an area of 447 thousand hectares with production of 7.16 MT and contribute about 3.90 percent in country's vegetable production (Anonymous, 2018).

Marketing of vegetable crops is quite complex and risky due to the perishable nature of the produce, seasonal production and bulkiness. The spectrum of prices from producer to consumer, which is an outcome of demand and supply of transactions between various intermediaries at different levels in the marketing system, is also unique for vegetables. Moreover, the marketing arrangements at different stages also play an important role in price levels at various stages viz. from farm gate to the ultimate user. These features make the marketing system of vegetables to differ from other agricultural commodities, particularly in providing time, form and space utilities. Indian farmers typically depend heavily on middlemen particularly in fruits and vegetables marketing. The producers and the consumers often get a poor deal and the middlemen control the market, but do not add much value. There is also massive wastage, deterioration in quality as well as frequent mismatch between demand and supply both spatially and over time. Successful commercial fresh vegetable production is a demanding task that requires a combination of production and marketing skills from the growers. For instance, the perishability of fresh vegetables leads to fewer storage opportunities compared to other agronomic crops. As a result, farmers are compelled to sell their products at the harvest time when the prices are minimal resulting in a very low return for their produced products. Ultimately, the farmers who produce and bear the risks associated with the crop production are deprived of the major benefits of their products.

To overcome the risks and to give right price of vegetables to its growers, Haryana government has launched Bhavanter Bharpai Yojna (BBY) in January, 2018. The main objective of this scheme is to assure farmers of fair prices for their produce and emphasizing on diversification of crops. According to the scheme, farmers will not have to sell their vegetables at a lower price than the minimum support price. If they have to, then government will provide compensation (bharpai) equivalent to the deficit (anter) in the price (bhav). By launching this scheme, Haryana became the first state in the country where the minimum preserved prices of vegetables have been fixed to protect the interests of farmers. Four vegetable crops viz; tomato, onion, potato and cauliflower have been included under the scheme and compensation at the rate of Rs 400 per quintal fixed for tomato and potato, whereas Rs 500 per quintal fixed for onion and cauliflower. It is also ensured that registered farmer under the scheme, will get at least the income of Rs. 48000 to Rs. 50000 per acre on each of the above four crops. To popularize the scheme among vegetable growers, large numbers of awareness camps throughout Haryana were conducted by horticulture department of the state and help of print and social media was also taken to give wide publicity to the scheme. Since the scheme was launched by the government keeping in view the risks associated with 
vegetable farmers and ensure fixed income on cultivation of vegetables, so it was felt necessary to know the vegetable growers' perceptions towards BBY and how much awareness they have about the scheme. Therefore, the present study was undertaken to know awareness and perception of vegetable growers about Bhavantar Bharpai Yojna in Haryana.

\section{Materials and Methods}

The study was conducted in randomly selected Hisar and Fatehabad districts of Haryana during the year 2019. From each selected district, list of villages where vegetables are being grown was collected from district horticulture department and from that list; four villages from each district were selected randomly. Thus eight villages viz. Akanwali, PuranMajra, Sidhani \& Majra of Fatehabad district and Raipur, Sikarpur, Dhani-Piranwali \& Hansi rural of Hisar district were selected for this study. From each selected village, 10 vegetable growers were selected randomly. Thus, 80 vegetable growers from eight villages were selected for the present study. The data were collected through well structured, pre- tested interview schedule prepared for this purpose. The data, so collected, were computed, analyzed and tabulated by using appropriate statistical methods.

\section{Results and Discussion}

\section{Profile of vegetable growers}

The profile of an individual such as age, education, farming experience and information source utilization etc. plays an important role in influencing one's behavior. So the extent of these variables was thoroughly studied. The data pertaining to socio- personal attributes of vegetable growers presented in Table 1 indicates that
47.50 per cent of respondents belong to middle age group followed by young age group (40.00\%). Majority (65\%) of respondents had farming experience of more than 15 yrs. The data regarding educational qualification reveals that 32.50 percent respondents were educated up to metric while 28.75 percent respondents were having higher secondary \& above educational qualification. 47.50 per cent of respondents belong to small farmer category followed by medium farmer category $(25.00 \%)$ on the basis of land holding. A vast majority (90\%) of respondents had agriculture as their main occupation followed by agriculture plus allied occupation $(10.00 \%)$ and agriculture plus service (2.5\%). Majority (61.25\%) of respondents had both the sources of irrigation i.e. canal and tube well.

\section{Information sources utilization}

The information sources utilized by the vegetable growers for seeking information related to agriculture, horticulture etc. were categorized in three categories i.e. Institutional sources, non-institutional sources and media sources and responses were obtained on four- point continuum. The preference of respondents regarding utilization of information sources was decided by giving them ranks on the basis of weighted mean score (WMS).The data regarding utilization of information sources presented in Table 2 reveals that among institutional sources, government departments (agriculture, horticulture etc.) ranks first with WMS of 2.61 followed by cooperatives ( $\mathrm{WMS}=2.40$ ) and research/extension/training institutes (WMS=2..08). Whereas in case of noninstitutional sources, vegetable growers prefers to seek information from friends (WMS=3.31), input dealers (WMS=3.25), neighbors (WMS=3.00) and progressive farmers (WMS=2.93). In case of media source utilization, Television ranks first 
followed by farmers fair/krishimela/field days, newspaper, cell phones and exposure visits. Therefore on the basis of above findings, it is concluded that vegetable growers prefers to seek information from government departments, friends and agricultural programmes on television among available institutional, non-institutional and media sources respectively.

\section{Awareness of vegetable growers about} bhavanter bharpai yojana

It is apparent from the data presented in Table 3 that majority $(82.00 \%)$ of the respondents were aware that BBY is being implemented in the state. More than 50 per cent of respondents had awareness regarding implementing agency, its objectives, crops included under the scheme and eligibility of farmers under the scheme. But most of the respondents (more than $60 \%$ ) were not aware about registration process, area verification, sale period, procedure of claiming benefit under BBY. About 60 per cent of respondents were not aware about Toll Free Helpline number of the scheme. Average mean score of 6.85 indicated that respondents had not sufficient awareness about BBY. The overall awareness about BBY was measured 45.66 per cent. These responses point towards the need to develop extension strategies which should focus on information dissemination and awareness generation. The implementing agencies should make some more serious efforts to create awareness among vegetable growers about BBY. Overall analysis of the data regarding awareness indicates that respondents' know that scheme is being implemented in the state but they have very poor awareness regarding registration process on portal of scheme, area to be verified from implementing department and procedure for claiming benefit under the scheme. Even most of the respondents $(60 \%)$ do not know the Toll free Helpline No. of the scheme.
Therefore, it is suggested that awareness among vegetable growers should be increased through organization of farmers' group meetings, kisangosthies etc. at village level and in these awareness programmes, more emphasis should be given to make aware farmers about registration process on portal, area verification and procedure for claiming benefit under the scheme.

\section{Vegetable growers' perception about bhavanter bharpaiyojana}

Perception is very important in understanding the human behavior. Perception about BBY refers to identification and interpretation of sensory information in order to represent and understand BBY. For measuring perception about BBY, A teacher made test was constructed and administered to the respondents for obtaining their responses. The test consist of 18 statements and response of respondents against each statement was obtained in two point continuum i.e. agree and disagree. Total and weighted mean score of each statement was calculated and assigned rank order for each statement. The data regarding vegetable growers perception about BBY presented in Table 4 reveals that 86.25 per cent respondents agree with the statement that ' $\mathrm{BBY}$ is not much beneficial in the present scenario of vegetable prices (WMS=0.86) followed by the statement 'BBY is not effective without awareness (WMS $=0.85$ )', BBY is not beneficial for farmers as daily price of vegetables are fixed on the basis of average daily price of 25 to 30 identified sabjimandies, not on the basis of local mandies where actually the farmers sell his produce $(\mathrm{WMS}=0.84$ ), Simplification of process is required for BBY effectiveness( $\mathrm{WMS}=0.83$ ), On line registration of $\mathrm{BBY}$ is a big hurdle for less educated/ illiterate farmers(WMS=0.81) were ranked First, second, third, fourth \& fifth respectively. Whereas statements 'BBY reduces the risk of 
low price of vegetables in market during glut production (WMS $=0.78$ )', BBY is also beneficial for farmers who cultivate on leased or on shared basis (WMS=0.75), BBY incentivize the farmers during low prices of their vegetables in market (WMS $=0.73$ ), $\mathrm{BBY}$ ensures fixed income per acre (WMS $=0.70$ ), Proper knowledge about BBY is very much essential (WMS=0.65) were ranked sixth, seventh, eighth, ninth and tenth, respectively. From above results, it can be concluded that BBY can be effective if the rates of the crops included in the schemes should be increased and daily prices should be fixed on the basis of local sabji-mandies of the district. Awareness among vegetable growers about BBY and simplification of registration process make BBY effective as perceived by the respondents. BBY was perceived beneficial as it reduces the risk of low price of vegetables in market during glut production and also beneficial for farmers who cultivate on leased or on shared basis. Respondents perceived that, BBY incentivize the farmers during low prices of their vegetables in market and ensures fixed income per acre.

Table.1 Profile of Vegetable Growers N=80

\begin{tabular}{|c|c|c|c|c|}
\hline S. No. & Variable & Category & Frequency (No.) & Percentage \\
\hline \multirow[t]{3}{*}{1} & \multirow[t]{3}{*}{ Age } & Young (up to 37 years) & 32 & 40.00 \\
\hline & & Middle (38-55 years) & 38 & 47.50 \\
\hline & & Old (above 55 years) & 10 & 12.50 \\
\hline \multirow[t]{3}{*}{2} & \multirow[t]{3}{*}{ Experience } & Up to 15 years & 28 & 35.00 \\
\hline & & $16-30$ years & 34 & 42.50 \\
\hline & & $>30$ years & 18 & 22.50 \\
\hline \multirow[t]{7}{*}{3} & \multirow[t]{7}{*}{ Education } & Illiterate & 04 & 5.00 \\
\hline & & Primary & 15 & 18.75 \\
\hline & & Middle & 12 & 15.00 \\
\hline & & Matriculation & 26 & 32.50 \\
\hline & & Higher secondary & 11 & 13.75 \\
\hline & & Graduate & 08 & 10.00 \\
\hline & & Post graduate & 04 & 5.00 \\
\hline \multirow[t]{4}{*}{4} & \multirow[t]{4}{*}{ Land holding } & Marginal farmers $(<2.5$ acres $)$ & 17 & 21.25 \\
\hline & & Small farmers ( $>2.5$ to 5 acres $)$ & 38 & 47.50 \\
\hline & & Medium farmers (> 5 to 10 acres) & 20 & 25.00 \\
\hline & & Large farmers ( > 10acres) & 5 & 6.25 \\
\hline \multirow[t]{3}{*}{5} & \multirow[t]{3}{*}{ Occupation } & Agriculture & 70 & 87.50 \\
\hline & & Agriculture + allied occupation & 08 & 10.00 \\
\hline & & Agriculture + Service & 02 & 2.50 \\
\hline \multirow[t]{3}{*}{6.} & \multirow{3}{*}{$\begin{array}{l}\text { Irrigation } \\
\text { sources }\end{array}$} & Tube well/Submersible Pump & 14 & 17.25 \\
\hline & & Canal & 17 & 21.25 \\
\hline & & Both & 49 & 61.25 \\
\hline
\end{tabular}


Table.2 Information sources utilization by vegetable growers $\mathrm{N}=80$

\begin{tabular}{|c|c|c|c|c|c|c|c|c|}
\hline \multirow{2}{*}{$\begin{array}{l}\text { Sr. } \\
\text { No. }\end{array}$} & \multirow{2}{*}{$\begin{array}{l}\text { Information } \\
\text { sources }\end{array}$} & \multicolumn{4}{|c|}{ Utilization } & \multirow{2}{*}{$\begin{array}{l}\text { Total } \\
\text { score }\end{array}$} & \multirow{2}{*}{$\begin{array}{l}\text { Weighted } \\
\text { Mean } \\
\text { Score }\end{array}$} & \multirow{2}{*}{$\begin{array}{l}\text { Rank } \\
\text { order }\end{array}$} \\
\hline & & Regular & Sometimes & Rarely & Never & & & \\
\hline \multicolumn{9}{|c|}{ A. Institutional sources } \\
\hline 1 & $\begin{array}{l}\text { Research/Extension/Training } \\
\text { institutions (ICAR/SAUs/KVKs) }\end{array}$ & $8(32)$ & $14(42)$ & $35(70)$ & $23(23)$ & 167 & 2.08 & III \\
\hline 2 & $\begin{array}{l}\text { Government departments } \\
\text { (Agri./Horti./Animal Husbandry } \\
\text { etc.) }\end{array}$ & $18(72)$ & $26(78)$ & $23(46)$ & $13(13)$ & 209 & 2.61 & $\mathbf{I}$ \\
\hline 3 & Cooperative/ commodity board/ & $14(56)$ & $22(66)$ & $26(52)$ & $18(18)$ & 192 & 2.40 & II \\
\hline 4 & $\begin{array}{l}\text { Corporate/ Private companies } \\
\text { etc. }\end{array}$ & $02(8)$ & $6(18)$ & $4(8)$ & $68(68)$ & 102 & 1.27 & IV \\
\hline \multicolumn{9}{|c|}{ B. Non-Institutional sources } \\
\hline 1 & Progressive farmers & $30(120)$ & $26(78)$ & $12(24)$ & $12(12)$ & 234 & 2.93 & IV \\
\hline 2 & Friends & $42(168)$ & $25(75)$ & $9(18)$ & $4(4)$ & 265 & 3.31 & I \\
\hline 3 & Relatives & $12(48)$ & $20(60)$ & $32(64)$ & $16(16)$ & 188 & 2.35 & VI \\
\hline 4 & Neighbors & $25(100)$ & $35(105)$ & $15(30)$ & $5(5)$ & 240 & 3 & III \\
\hline 5 & Other farmers & $20(80)$ & $28(84)$ & $17(34)$ & $15(15)$ & 213 & 2.66 & V \\
\hline 6 & $\begin{array}{l}\text { Farmers Associations (FIGs, } \\
\text { CIGs, Kisan Club) }\end{array}$ & $4(16)$ & $8(24)$ & $22(44)$ & $46(46)$ & 130 & 1.63 & VII \\
\hline 7 & Input dealers & $48(192)$ & $12(36)$ & $12(24)$ & $8(8)$ & 260 & 3.25 & II \\
\hline \multicolumn{9}{|c|}{ C. Media sources } \\
\hline 1 & Radio & $04(16)$ & $20(60)$ & $18(36)$ & $38(38)$ & 150 & 1.88 & $\mathbf{X}$ \\
\hline 2 & $\begin{array}{l}\text { Agricultural Column in News } \\
\text { paper }\end{array}$ & $12(48)$ & $32(96)$ & $6(12)$ & $30(30)$ & 186 & 2.33 & III \\
\hline 3 & $\begin{array}{l}\text { Agricultural programmes on } \\
\text { Television }\end{array}$ & $22(88)$ & $28(84)$ & $21(42)$ & $9(9)$ & 223 & 2.79 & $\mathbf{I}$ \\
\hline 4 & Cell phones(SMS, Voice Calls) & $9(36)$ & $17(51)$ & $32(64)$ & $22(22)$ & 173 & 2.16 & IV \\
\hline 5 & $\begin{array}{l}\text { Demonstrations/ Seminars/ } \\
\text { conferences }\end{array}$ & $5(20)$ & $12(36)$ & $16(32)$ & $47(47)$ & 135 & 1.69 & $\mathbf{X I}$ \\
\hline 6 & Exposure visits & $8(32)$ & $26(78)$ & $15(30)$ & $31(31)$ & 171 & 2.14 & $\mathbf{V}$ \\
\hline 7 & Publication of private agencies & $15(60)$ & $12(36)$ & $13(26)$ & $40(40)$ & 162 & 2.03 & IX \\
\hline 8 & $\begin{array}{l}\text { Farmers Fair/ Krishimelas/ Field } \\
\text { days }\end{array}$ & $17(68)$ & $26(78)$ & $16(32)$ & $21(21)$ & 199 & 2.49 & II \\
\hline 9 & Agro-industrial Exhibitions & $23(92)$ & $08(24)$ & $02(4)$ & $47(47)$ & 167 & 2.09 & VII \\
\hline 10 & Internet & $15(60)$ & $18(54)$ & $4(8)$ & $43(43)$ & 165 & 2.06 & VIII \\
\hline 11 & Farm Magazines & $4(16)$ & $23(69)$ & $32(64)$ & $21(21)$ & 170 & 2.13 & VI \\
\hline
\end{tabular}

Figure in parentheses indicate score obtained by respondents 
Table.3 Vegetable Growers' awareness about Bhavanter Bharpai Yojana N=80

\begin{tabular}{|c|c|c|c|c|c|}
\hline \multirow{3}{*}{$\begin{array}{l}\text { Sr. } \\
\text { No }\end{array}$} & \multirow[t]{3}{*}{ Statements } & \multicolumn{4}{|c|}{ Awareness Level } \\
\hline & & \multicolumn{2}{|c|}{ Aware } & \multicolumn{2}{|c|}{ Not aware } \\
\hline & & $\mathbf{F}$ & \%age & $\mathbf{F}$ & \%age \\
\hline 1 & Awareness about implementation of BBY in the state & 66 & 82.50 & 14 & 17.50 \\
\hline 2 & Awareness about the objectives of BBY & 44 & 55.00 & 36 & 45.00 \\
\hline 3 & $\begin{array}{l}\text { Awareness about the department implementing the } \\
\text { scheme }\end{array}$ & 60 & 75.00 & 20 & 25.00 \\
\hline 4 & Awareness about crops included in BBY & 42 & 52.50 & 38 & 47.50 \\
\hline 5 & $\begin{array}{l}\text { Awareness about the secured price fixed for the crops } \\
\text { included in the scheme? }\end{array}$ & 38 & 47.50 & 42 & 52.50 \\
\hline 6 & $\begin{array}{l}\text { Awareness about the benchmark yield fixed for the crops } \\
\text { under the scheme? }\end{array}$ & 36 & 45.00 & 44 & 55.00 \\
\hline 7 & Awareness about the eligibility of farmers for the scheme & 41 & 51.25 & 39 & 48.75 \\
\hline 8 & Awareness about the registration process on the portal & 28 & 35.00 & 52 & 65.00 \\
\hline 9 & $\begin{array}{l}\text { Awareness about registration and closing dates for the } \\
\text { crops under in the scheme }\end{array}$ & 29 & 36.25 & 51 & 63.75 \\
\hline 10 & $\begin{array}{l}\text { Awareness about the compulsion of area verification under } \\
\text { the crops }\end{array}$ & 22 & 27.50 & 58 & 72.50 \\
\hline 11 & Awareness about sale period. & 26 & 32.50 & 54 & 67.50 \\
\hline 12 & Awareness about appeal against area verification & 20 & 25.00 & 60 & 75.00 \\
\hline 13 & $\begin{array}{l}\text { Awareness about sale of produce on J- form under the } \\
\text { scheme }\end{array}$ & 36 & 45.00 & 44 & 55.00 \\
\hline 14 & $\begin{array}{l}\text { Awareness about procedure for claiming benefit under the } \\
\text { scheme? }\end{array}$ & 28 & 35.00 & 52 & 65.00 \\
\hline 15 & Awareness about Toll free Helpline No. of the scheme & 32 & 40.00 & 48 & 60.00 \\
\hline \multicolumn{2}{|c|}{ Average Mean Score } & \multicolumn{4}{|c|}{6.85} \\
\hline \multicolumn{2}{|c|}{ Over all Awareness } & \multicolumn{4}{|c|}{$45.66 \%$} \\
\hline
\end{tabular}


Table.4 Perception of Vegetable Growers about Bhavanter Bharpai Yojana N=80

\begin{tabular}{|c|c|c|c|c|c|c|c|}
\hline \multirow{3}{*}{$\begin{array}{l}\text { Sr. } \\
\text { No. }\end{array}$} & \multirow[t]{3}{*}{ Statement } & \multicolumn{4}{|c|}{ Perception } & \multirow[t]{3}{*}{ WMS } & \multirow{3}{*}{$\begin{array}{l}\text { Rank } \\
\text { order }\end{array}$} \\
\hline & & \multicolumn{2}{|c|}{ Agree } & \multicolumn{2}{|c|}{ Disagree } & & \\
\hline & & $\mathbf{F}$ & $\%$ & $\mathbf{F}$ & $\%$ & & \\
\hline 1. & $\begin{array}{l}\text { BBY motivates farmers for diversification } \\
\text { in agriculture through vegetables }\end{array}$ & 50 & 62.50 & 30 & 37.50 & 0.63 & XI \\
\hline 2. & $\begin{array}{l}\text { BBY incentivize the farmers during low } \\
\text { prices of their vegetables in market }\end{array}$ & 58 & 72.50 & 22 & 27.50 & 0.73 & VIII \\
\hline 3. & $\begin{array}{l}\text { BBY reduces the risk of low price of } \\
\text { vegetables in market during glut production }\end{array}$ & 62 & 70.50 & 18 & 22.50 & 0.78 & VI \\
\hline 4. & BBY ensures fixed income per acre & 56 & 70.00 & 24 & 30.00 & 0.70 & IX \\
\hline 5 & $\begin{array}{l}\text { BBY is also beneficial for farmers who } \\
\text { cultivate on leased or on shared basis }\end{array}$ & 60 & 75.00 & 20 & 25.00 & 0.75 & VII \\
\hline 6. & $\begin{array}{l}\text { Area enhancement as well as } \\
\text { intensification of vegetable especially } \\
\text { Tomato, Potato, Onion and Cauliflower }\end{array}$ & 44 & 55.00 & 36 & 45.00 & 0.55 & XIII \\
\hline 7. & BBY is not effective without awareness. & 68 & 85.00 & 12 & 15.00 & 0.85 & II \\
\hline 8. & $\begin{array}{l}\text { On line registration of BBY is a big hurdle } \\
\text { for less educated/ illiterate farmers. }\end{array}$ & 65 & 81.25 & 15 & 18.75 & 0.81 & V \\
\hline 9 & $\begin{array}{l}\text { BBY is not much beneficial in the present } \\
\text { scenario of vegetable prices }\end{array}$ & 69 & 86.25 & 11 & 13.75 & 0.86 & I \\
\hline 10 & $\begin{array}{l}\text { BBY is not beneficial for farmers as daily } \\
\text { price of vegetables are fixed on the basis of } \\
\text { average daily price of marked identified } \\
\text { sabji-mandies, not on the basis of local } \\
\text { mandies where actually the farmers sell his } \\
\text { produce }\end{array}$ & 67 & 83.75 & 13 & 16.25 & 0.84 & III \\
\hline 11. & $\begin{array}{l}\text { Sale of produce on J-Form on daily basis } \\
\text { makes BBY cumbersome. }\end{array}$ & 49 & 61.25 & 31 & 38.75 & 0.61 & XII \\
\hline 12. & $\begin{array}{l}\text { Proper knowledge about BBY is very much } \\
\text { essential. }\end{array}$ & 52 & 65.00 & 28 & 35.00 & 0.65 & $\mathrm{X}$ \\
\hline 13 & $\begin{array}{l}\text { Simplification of process is required for } \\
\text { BBY effectiveness. }\end{array}$ & 66 & 82.50 & 14 & 17.50 & 0.83 & IV \\
\hline 14 & $\begin{array}{l}\text { BBY has increased the nutritive diet among } \\
\text { rural }\end{array}$ & 42 & 52.50 & 38 & 47.50 & 0.53 & XIV \\
\hline 15 & $\begin{array}{l}\text { BBY has increased the net income of } \\
\text { farmers }\end{array}$ & 36 & 45.00 & 44 & 55.00 & 0.45 & XVII \\
\hline 16 & $\begin{array}{l}\text { BBY may include some more vegetables \& } \\
\text { cereals }\end{array}$ & 41 & 51.25 & 39 & 48.75 & 0.51 & XV \\
\hline 17 & $\begin{array}{l}\text { BBY may increases the employment/ men } \\
\text { days in rural area }\end{array}$ & 37 & 46.25 & 43 & 53.75 & 0.46 & XVI \\
\hline 18 & $\begin{array}{l}\text { BBY may provide income to farmers round } \\
\text { the year }\end{array}$ & 33 & 41.25 & 47 & 58.75 & 0.41 & $\begin{array}{c}\text { XVII } \\
\text { I }\end{array}$ \\
\hline
\end{tabular}


From the above findings, it can be concluded that respondents had not sufficient awareness about BBY as overall awareness measured was 45.66 per cent. The responses point out need to develop suitable extension strategies which should focus on information dissemination and awareness generation. Although respondents' knows that scheme is being implemented in the state but they have very poor awareness regarding registration process on portal of scheme, area to be verified from implementing department and procedure for claiming benefit under the scheme.

Even most of the respondents do not know about Toll free Helpline No. of the scheme. Therefore, it is suggested that awareness among vegetable growers should be increased through organization of farmers' group meetings, kisangosthies etc. at village level and in these awareness programmes, more emphasis should be given to make aware farmers about registration process on portal, area verification and procedure for claiming benefit under the scheme. Most of the vegetable growers have perception that BBY reduces the risk of low price of vegetables in market during glut production and it is also beneficial for farmers who cultivate on leased or on shared basis. BBY incentivize the farmers during low prices of their vegetables in market and ensures fixed income per acre. The respondents agree with the perception statements that BBY is not much beneficial in the present scenario of vegetable prices and it will not be effective without awareness. Therefore, on the basis of above finding, it is suggested that the rates of the crops included in the schemes should be increased and registration process under BBY should be simplified.

\section{References}

Annonymous. 2018. Horticulture statistics at a glance. Department of Agriculture, Cooperation \& Farmers' Welfare. Ministry of Agriculture \& Farmers' Welfare Government of India. Pp. 1490.

Dastagiri M. B., Chand R., ImmanuelrajT. K, HanumanthaiahC. V., ParamsivamP., Sidhu R. S., SudhaM.,Mandal S., Singh B., Chand K., Kumar B. G. 2013. Indian Vegetables: Production Trends, Marketing Efficiency and Export Competitive-ness. American Journal of Agriculture and Forestry.1(1):1-11

Kumar Ajay, Sumit, Yadav M. K. and Rohila, A.K. 2019. Constraints faced by the Farmers in Production and Marketing of Vegetables in Haryana, Indian Journal of Agricultural Sciences. 89 (1): 153-60.

Kumar P., ChauhanR. S., Tanwar N., GroverR. K. 2018. Status and Constraints in Vegetable Cultivation under polyhouse in Haryana. Advances in Bioresearch. 9 (2):61-66.

NainM.S., Singh R. and MishraJ.R. 2017. A Study of Farmers' Awareness on Agricultural Insurance Schemes in Southern Haryana. Indian Journal of Extension Education. 53 (4):75-79.

\section{How to cite this article:}

Sandeep Bhakar, Sube Singh and Sheharawat. P. S. 2020. Vegetable Growers Perception and Awareness about Bhavantar Bharpai Yojna in Haryana. Int.J.Curr.Microbiol.App.Sci. 9(06): 2152-2160. doi: https://doi.org/10.20546/ijcmas.2020.906.263 